\title{
Walter Burley on the Incipit and Desinit of an Instant of Time
}

\author{
Cecilia Trifogli \\ University of Oxford, Oxford, England \\ cecilia.trifogli@all-souls.ox.ac.uk
}

\begin{abstract}
Walter Burley (ca. 1275-after 1344) is the author of a treatise, entitled De primo et ultimo instanti, which is regarded as the most popular medieval work on the problem of assigning first and last instants of being to permanent things. In this paper, however, I do not deal with this treatise directly. I look instead at how Burley applies the ideas presented in it to the solution of an Aristotelian puzzle about the ceasing to be (i.e., to exist) of the present instant (Physics IV, 10). In Burley's interpretation, the relevant question raised by the puzzle is whether the present instant ceases to be when it is or when it is not. While Aristotle's argument quickly dismisses the first alternative as absurd, Burley defends it by appealing to the 'expositions' of sentences about ceasing (desinit). Given that the sentence 'this instant ceases to be' has two expositions - (1) 'this instant now is and immediately afterwards will not be' (position of the present and negation of the future) or (2) 'this instant now is not and immediately beforehand was' (negation of the present and position of the past) - Burley maintains that the sentence is true in exposition (1) but not true in exposition (2), so that an instant ceases to be when it is and not when it is not.
\end{abstract}

\section{Keywords}

Walter Burley - instant of time - beginning - ceasing

In his treatise De primo et ultimo instanti Walter Burley (ca. 1275-after 1344) ${ }^{1}$ deals with the question of assigning temporal limits to the existence of permanent things: in his own words,

${ }^{1}$ On Walter Burley, see the recent collection of essays A Companion to Walter Burley: Late Medieval Logician and Metaphysician, ed. A.D. Conti (Leiden, 2013). 
with the question 'Whether we must grant a first and a last instant in which a permanent thing has being' (Utrum sit dare primum et ultimum instans in quo res permanens habeat esse). ${ }^{2}$ In focusing on the class of permanent things only, Burley assumes that the question of assigning temporal limits to the being of the other relevant class of things, that of successive things (typically, change), 3 has already been satisfactorily settled by Aristotle in his discussion of the continuity of change in Physics VI. ${ }^{4}$ Following a standard interpretation of this discussion, Burley thinks that Aristotle's considered view there is that no first or last instant of the being of a change or more generally of a successive thing should be posited. Burley is perfectly happy with Aristotle's view so that he feels that there is no need to raise the question of the temporal limits of successive things again. For permanent things, however, Burley thinks that the question has been left open or given only a very partial answer by Aristotle. 5

Burley locates Aristotle's view on the temporal limits of permanent things in a famous passage of Physics VIII, 8, about the so-called instant of change, where Aristotle argues that the

${ }^{2}$ Burley's treatise is edited in H. and C. Shapiro, "De primo et ultimo instanti des Walter Burley," Archiv für Geschichte der Philosophie 47 (1965), 159-173. This edition, however, is of very poor quality.

3 The distinction between permanent and successive things is a standard one among scholastic philosophers. A locus classicus for this distinction is Aristotle, Physics III, c. 6: 206a18-33. In his treatise Burley explains it as follows (ed. Shapiro and Shapiro, 164): “... sciendum quod differentia est inter rem (res ed.) permanentem et successivam, quoniam res permanens, communiter loquendo de re permanente, est illa cui non repugnat ex natura rei habere omnes partes simul. Et res successiva est illa cui repugnat ex natura rei habere omnes suas partes simul; ymo est de natura sui quod habeat unam partem priorem (per temporem ed.), et aliam posteriorem, et quando pars prior est, pars posterior non est. Lapis enim est res permanens, quia lapidi non repugnat habere omnes partes simul in eadem mensura. Sed dies et septimana, et sic de aliis, sunt res successive, quia eis repugnat habere omnes partes suas simul. Repugnat enim diei quod quando est hora prima quod sit tertia." According to this explanation, things without parts, like temporal instants and points, are permanent things.

${ }^{4}$ Aristotle, Physics VI, c. 5: 236a7-27; c. 6.

${ }^{5} \mathrm{~A}$ similar approach is found in Thomas Wylton, who probably was a teacher of Walter Burley and whose question on the incipit and desinit problem is very likely the main source of Burley's treatise. For the edition (with introduction) of Wylton's question, see C. Trifogli, "Thomas Wylton's Question 'An contingit dare ultimum rei permanentis in esse'," Medieval Philosophy and Theology 4 (1994), 91-141. 
instant of change, that is, the instant of transition from a permanent thing $\mathrm{A}$ and to a permanent thing $\mathrm{B}$ - for example, from being water to being air - belongs to the posterior thing $B$ and not to the prior thing A. ${ }^{6}$ Thus, in our example, the instant of change is the first instant in which air exists and not the last instant in which water exists. On the basis of this account of the instant of change, Burley ascribes to Aristotle the view that a permanent thing has a first instant of being but not a last instant of being. 7

Burley is not happy with Aristotle's view so defined, because he thinks that it is too general. It is supposed to be valid for all kinds of permanent thing, but actually this is not so. Thus, he devotes his treatise De primo et ultimo instanti to distinguishing relevant classes of permanent things and to establishing to which of them a first or last instant of being is to be ascribed or denied.

The first class of permanent things singled out by Burley is that of things that last for only one instant, that is, things that do not have a temporal duration: instantaneous things, for short. Examples of instantaneous things are the instantaneous phases of a change or of a local motion (e.g., the being of the mobile thing in a given place during its motion) and the instants of time (that is, temporally indivisible items of time analogous to the points of a line). This is a class of permanent things not considered by Aristotle. However, it is also a class of things for which the question about the temporal limits of their being does not seem to create any problems. There is a straightforward reply

${ }^{6}$ Aristotle, Physics VIII, c. 8: 263b9-15: "It is also plain that unless we hold that the point of time that divides earlier from later always belongs only to the later so far as the thing is concerned, we shall be involved in the consequence that the same thing at the same moment is and is not, and that a thing is not at the moment when it has become. It is true that the point is common to both times, the earlier as well as the later, and that, while numerically one and the same, it is not so in definition, being the end of one and the beginning of the other; but so far as the thing is concerned it always belongs to the later affection." English translation from The Complete Works of Aristotle. The Revised Oxford Translation, ed. J. Barnes (Princeton, NJ, 1984), vol. 1, 440. For a classical study of Aristotle's view, see R. Sorabji, "Aristotle on the Instant of Change," Proceedings of the Aristotelian Society Supplementary Volume 50 (1976), 69-89, revised version in Articles on Aristotle, ed. J. Barnes, M. Schofield, and R. Sorabji (London, 1979), vol. 3, 159-177.

7 Gualterus Burlaeus, De primo et ultimo instanti (ed. Shapiro and Shapiro, 159). 
to this question, namely, that an instantaneous thing has both a first and a last instant of its being. More explicitly, such a thing by definition lasts only one instant, say $t$. Instant $t$ then is both the first instant and the last instant of its being. The case of instantaneous things is indeed a trivial case and Burley settles it at the very beginning of his positive account and does not take it up again in the rest of the treatise. ${ }^{8}$

While the question about the temporal limits of an instantaneous thing seems to admit a straightforward answer when it is formulated in 'static' terms, so to say, that is, as a question about its being, matters become less intuitive when it is formulated in 'dynamic' terms, that is, in terms of the beginning and ceasing of the being of an instantaneous thing. Since such a thing only lasts for a single instant $t$, so that it did not exist before $t$ and will not exist after $t$, it makes sense to talk about the beginning to exist and the ceasing to exist of such a thing. The 'dynamic' version of the question then asks whether instant $t$ is the instant in which such a thing begins to be or whether it is the instant in which it ceases to be or whether it is both the instant in which it begins to be and in which it ceases to be. The answer to this question is less obvious than the answer in the 'static' case.

In this paper I will present Burley's discussion of the 'dynamic' version of the question about the temporal limits of instantaneous things. This discussion, absent from his treatise De primo et ultimo instanti, is found in the section of his commentary on Aristotle's Physics about time (Physics IV.10-14) in connection with a puzzle raised by Aristotle about the identity and diversity of the present instant of time. Thus, I will start by outlining the Aristotelian context of Burley's discussion.

${ }^{8}$ Gualterus Burlaeus, De primo et ultimo instanti (ed. Shapiro and Shapiro, 164): "Distinctio ulterius est de re permanente, quia quedam est res permanens, que (qua ed.) solum durat per unum instans, sicut mutatum esse, et instans in tempore, et ubi in medio motus. Unde lapis, si non haberet nisi unum instans, adhuc esset res permanens, quia habet omnes suas partes simul. Alia est res permanens que durat per tempus (tempore ed.) [...] Si loquitur de re que habet esse solum per unum instans, certum est quod tali rei est dare primum instans et ultimum instans sui esse, et quidem est primum instans et ultimum instans, sicut videmus de mutato esse, quod habet esse solum in hoc instanti. Unde de talibus rebus, questio non habet difficultatem." 
In the initial and dialectical phase of his treatment of time, Aristotle puts forward a puzzle about the now, i.e., the present instant. The puzzle arises when we ask a basic question about the identity and diversity of the now: is the now always different or always the same? Aristotle argues that we get into difficulties if we say either that the now is always different or that it is always the same. What is relevant for our purpose is the part of the puzzle about the alternative that the now is always different:

Again, it is not easy to see whether the now, which appears to be the boundary between past and future, remains always one and the same or is different from time to time. (a) If it is always different, and if no two distinct parts of things that are in time are simultaneous - except those of which one includes the other, as the greater time includes the smaller and if the now which is not but which previously was must have ceased to be at some time, then the nows too will not be simultaneous, and it must always be the case that the previous now has ceased-to-be. Now, that it has ceased-to-be in itself is not possible, because then it is; but it cannot be that the former now has ceased to be in another now, either. For we take it that it is impossible for the nows to be adjoining one another, as it is for a point to be adjoining a point; so, since the now has not ceased to be in the next now but in some other one, it will be simultaneously in the nows in between, which are infinitely many; but this is impossible. ${ }^{9}$

The first step in this puzzle is to turn the issue about now's being always different into an issue about its ceasing to be. This move is based on the assumption that there are no different constituents (either extended temporal parts or instants) of time that are (totally) temporally overlapping, that is, simultaneous. In particular, there are no two distinct overlapping instants, so that any two distinct instants exist one after the other. Therefore, if now $t$ is distinct from a later now $s$, now $t$ must have ceased to be when now $s$ is. The ceasing to be of now $t$, however, is problematic, because it seems that one cannot give a satisfactory

${ }^{9}$ Aristotle, Physics IV, c. 10: 218a8-21. The English translation is from Aristotle Physics. Books III and IV, trans. E. Hussey (Oxford, 1983), 41-42. 
account of the temporal aspects of its ceasing to be. Consider the basic question 'When has now $t$ ceased to be?' There are only two plausible answers to it: either now $t$ has ceased to be at $t$ or at a now $s$ later than $t$. But neither of these two answers seems to work. The first answer is ruled out because it would lead to the conclusion that now $t$ would be and not be (because it has ceased to be) at $t$. The second answer is further articulated: the later now $s$ should be either immediate to $t$ (i.e., immediately following $t$ ) or separated from $t$ by an intervening period of time. Because of the continuity of time, the first case is not possible: instants are not immediate one to another, but between any two instants there is a period of time and hence infinitely many instants. But the second case is not possible either because now $t$ would persist throughout the period of time between itself and now $s$, which is against the assumption that now $t$ lasts for exactly one instant or, more literally, against the assumption that there are no distinct instants that are simultaneous. ${ }^{10}$

Aristotle leaves this puzzle without an explicit solution. According to a standard medieval interpretation, supported by the authoritative view of Thomas Aquinas, Aristotle's implicit solution to it is to be found in a passage of Physics IV, 11, in which relying on an analogy between the now and the mobile body Aristotle maintains that the now is in a way always the same and in a way always different. ${ }^{11}$ This standard interpretation, however, is far from satisfactory. The problem is that in the passage of Physics IV, 11, Aristotle does not at all address the question about the ceasing to be of the now and the difficulties with the temporal aspects of it on which the puzzle of Physics IV, 10, is focussed. Thus, despite the fact that the passage of Physics IV, 11, offers explicit indications about Aristotle's considered view on the identity and diversity of the now, it leaves the puzzle without a proper solution. Burley, however, unlike Aquinas and many other Aristotelian commentators, does

${ }^{10}$ As Ursula Coope remarks, the way in which Aristotle deals with the second case shows that the question that he actually intends to ask is 'when has now $t$ first ceased to exist', so that if now $s$ answers this question, then $t$ does not exist at $s$ but exists at any instant before $s$ (and after $t$ ). See U. Coope, Time for Aristotle (Oxford, 2005), 26, n. 19.

${ }^{11}$ Aristotle, Physics IV, c. 11: 219b9-32; S. Thomae Aquinatis in octo libros Physicorum Aristotelis Expositio IV, 1. 18 (ed. P.M. Maggiòlo, Turin-Rome, 1954, 287). On the inadequacy of the passage of Physics IV, 11, to provide a solution to the puzzle of Physics IV, 10, see Coope, Time for Aristotle, 27-28. 
address the puzzle itself in its temporal formulation and provides a solution to it.

In his commentary on the Physics, ${ }^{12}$ Burley devotes a specific short question to the Aristotelian puzzle, a question that asks "Whether an instant can be subject to corruption" (An instans possit corrumpi), to which he gives a positive reply. The only contra-argument in this question is a concise paraphrase of the Aristotelian argument against the alternative that an instant is subject to corruption or has ceased to be. ${ }^{13}$ In his paraphrase, the relevant dilemma is formulated as follows: "If an instant is subject to corruption, then either this happens when that instant is or when it is not." Burley sides with the first horn of this dilemma. He maintains that an instant is subject to corruption when it is, so that an instant, say $t$, is subject to corruption at $t$. Contrary to what Aristotle's puzzle assumes, Burley argues that it does not follow from this that instant $t$ simultaneously is and is not when it is subject to corruption. Rather, instant $t$ both is and is subject to corruption at instant $t$, but it is not also the case that it is not at $t$.

Although, following the context of Aristotle's discussion, Burley's solution is explicitly formulated for the case of temporal instants, he clearly assumes that it is also valid for all instantaneous things. All things that last for only one instant, say $t$, are such that they both exist and are subject to corruption at $t$.

${ }^{12}$ My reference is to the final Physics commentary by Burley, which he began to write in 1324: Gualterus Burlaeus, In Physicam Aristotelis Expositio et Quaestiones (ed. Venice 1501; repr. Hildesheim, 1972).

13 Gualterus Burlaeus, In Physicam IV (ed. cit., f. 124rb): “Ad secundam dubitationem arguitur probando quod instans non potest corrumpi. Et hoc sic: si instans corrumpitur, aut quando est aut quando non est. Non quando est quia tunc simul esset et non esset. Nec quando non est quia vel in instanti mediato vel in instanti immediato. Non in instanti immediato quia instans non est immediatum instanti. Nec in instanti mediato quia instans semper manet donec corrumpitur. Si igitur instans corrumperetur in instanti mediato, sequitur quod instans maneret in toto illo medio; sed in illo medio sunt infinita instantia media; ergo idem instans numero maneret cum infinitis instantibus, quod est impossibile." 
Note that there is a discrepancy between the original Aristotelian puzzle and Burley's solution to it. The Aristotelian puzzle asks the question of when an instant has ceased to be/been corrupted, whereas Burley replies to the question of when an instant ceases to be/is subject to corruption. The difference is in the tenses of the relevant verbs: 'has ceased to be'/has been corrupted' in the perfect tense versus 'ceases to be'/'is subject to corruption' in the present tense. Now, as Ursula Coope explains, Aristotle's use of the perfect tense rather than the present tense is motivated by his assumption that "indivisible things do not go through a process of ceasing to exist. There is, then, no time at which an indivisible thing is (in the process of) ceasing to exist." 14 This raises the following question for Burley: in replying to the present-tense question, is he making the odd assumption that there is something like a process of ceasing to be for an indivisible thing? Or is it rather the case that he can make sense of the present-tense question without making this assumption? As we shall see in the next section, Burley explicitly addresses this question. Actually, an essential ingredient of his solution is to specify a notion of corruption or ceasing to be that applies to indivisible things without violating the assumption that such things are not subject to any process or change. There are, however, other two questions about Burley's solution. To see this, consider that it is clear that any plausible reply to the pasttense question must save the condition that an instant is not when it has ceased to be/has been corrupted, as the Aristotelian puzzle obviously assumes. On the other hand, Burley's reply to the present-tense question is that the instant ceases to be/is subject to corruption when it is. Thus, for his reply to be plausible at all, he must assume that saying that an instant ceases to be/is subject to corruption is relevantly different from saying that an instant has ceased to be/has been corrupted. The first additional question therefore is: how does Burley distinguish between the case of the having ceased to be and that of the ceasing to be of an instant? And the second is: how does he reply to the question about the having ceased to be of an instant? Although Burley does not explicitly address these two questions, we shall see that his discussion contains a reply to both.

\footnotetext{
${ }^{14}$ Coope, Time for Aristotle, 27.
} 


\section{The Distinction between Corruption Taken Strictly and Corruption Taken Broadly}

Burley defends a qualified version of the thesis that an instant (or more generally an instantaneous thing) can be subject to corruption. An instant cannot be subject to corruption if corruption is taken strictly but it can be subject to corruption if corruption is taken broadly. Crucial to Burley's solution to the Aristotelian puzzle, then, is the distinction between corruption strictly and corruption broadly.

Burley presents this distinction at the very beginning of his reply to the question about the corruption of an instant:

In reply to the question whether an instant can be subject to corruption, I say that corruption can be taken in two ways, in the proper way and in a broad way. Corruption taken in the proper way is a change from the being of a thing to its non-being, whereas corruption taken in a broad way is the ceasing of the being of that thing, that is, corruption taken in a broad way is having non-being after being. ${ }^{15}$

A corruption taken strictly (or properly) is a passage from the being of a thing to its non-being that involves a change (mutatio): a thing is subject to corruption taken strictly when it passes from being to non-being through a change. A corruption taken broadly is the ceasing (desinitio) to be of a thing: a passage from being to non-being that does not necessarily involve a change.

Immediately after introducing this distinction, Burley makes the point that instants or more generally things that last for only one instant cannot be subject to corruption taken properly:

Thus, I say that, if we speak of corruption properly, then an instant is not subject to corruption or to generation, nor is an indivisible or something that exists only for one instant

15 Gualterus Burlaeus, In Physicam IV (ed. cit., f. 124vb): “Ad secundum dubium, quando quaeritur utrum instans possit corrumpi, dico quod corruptio potest accipi dupliciter, proprie et large. Proprie loquendo corruptio est mutatio ab esse rei in non esse eiusdem rei, sed corruptio largo modo accepta est desinitio illius esse, hoc est corrumpi largo modo accipiendo corruptionem est habere non esse post esse." 
subject to corruption taken properly. And this is the intention of the Philosopher in Metaphysics III, who says that there are things that sometimes are and sometimes are not without generation and corruption, that is, indivisibles, such as points, surfaces and instants. Therefore, I say that if we speak of corruption properly, which is a change whose terminus is the non-being of the thing that is subject to corruption, then an instant cannot be subject to corruption $[\ldots] .{ }^{16}$

The reference to Aristotle's Metaphysics makes it clear that Burley is well aware of the Aristotelian assumption that indivisible things are not subject to corruption and generation. ${ }^{17}$ It seems, however, that, in his view, a satisfactory interpretation of the Aristotelian passage does require a distinction between two kinds of generation and corruption; for, on one hand, Aristotle denies that indivisible things are subject to generation and corruption, but, on the other hand, he admits that such things may come into existence and pass out of it, and thus may

${ }^{16}$ Gualterus Burlaeus, In Physicam IV (ed. cit., f. 124vb): "Et sic dico quod, proprie loquendo de corruptione, sic instans non corrumpitur nec generatur nec etiam corrumpitur proprie aliquod indivisibile nec aliquod habens esse per instans tantum. Et haec est intentio Philosophi 3 Metaphysicae, qui dicit quod quaedam sunt quae quandoque sunt et quandoque non sunt sine generatione et corruptione, ut indivisibilia, cuiusmodi sunt puncta, superficies et instantia. Dico igitur quod proprie loquendo de corruptione quae est mutatio per se terminata ad non esse illius quod corrumpitur sic instans non potest corrumpi [...]."

${ }^{17}$ Aristotle, Metaphysics III, c. 5: 1002a28-bi1: "For besides what has been said, the questions of generation and destruction confront us with further paradoxes. For if substance, not having existed before, now exists, or having existed before, afterwards does not exist, this change is thought to be accompanied by a process of becoming or perishing; but points and lines and surfaces cannot be in process of becoming nor of perishing, though at one time exist and at another do not [...]. And if the boundaries come into being and cease to be, from what do they come into being? A similar account may also be given of the 'now' in time; for this also cannot be in process of coming into being or ceasing to be, but yet seems to be always different, which shows that it is not a substance. And evidently the same is true of points and lines and planes; for the same argument applies, as they are all alike either limits or divisions." English translation from The Complete Works of Aristotle. The Revised Oxford Translation, ed. J. Barnes (Princeton, NJ, 1984), vol. 2, 1583. Note the explicit mention of the 'now' at the end of this passage. 
be subject to some kind of generation and corruption, understood broadly as a passage from non-being to being and from being to non-being respectively.

Burley's short description of the distinction between corruption taken strictly and corruption taken broadly, however, is not particularly illuminating. In fact, we learn more about this distinction from how Burley applies it to the case of instants. Burley first argues that an instant cannot be subject to corruption strictly. His argument is the following:

I prove this claim as follows. A thing that is corruptible in the proper way always has being until it is corrupted. Moreover, the corruption that is a change, since it is sudden, occurs simultaneously with the terminus of the change. From these premises I argue as follows. If an instant were subject to corruption taken in the proper way, then that instant would always persist until its corruption occurs. Therefore, if an instant is subject to corruption, then either it is subject to corruption in the instant in which it is or in another instant. (i) If in the instant in which it is, that is, when it is, then that instant would be simultaneous with its corruption; but the corruption that is a change is simultaneous with its terminus, and the terminus of a corruption is the non-being of the thing that is subject to corruption; therefore, if an instant is subject to corruption when it is, then that instant would be simultaneous with its non-being and thus that instant would simultaneously be and not be, which is impossible. (ii) Nor is it possible to maintain that an instant is subject to corruption in another instant, because then that instant would continuously persist until another instant in which it is subject to corruption, and thus that instant would persist for the whole time intervening between itself and the instant of its corruption, which is impossible. Therefore, I say that an instant is not subject to corruption taken in the proper way. This argument lies on two foundations. The first is that a sudden corruption is simultaneous with its terminus. The second is that the thing subject to corruption persists until 
the instant of its corruption. And these premises are per se known. ${ }^{18}$

In this argument Burley appeals to two conditions that a corruption taken strictly must satisfy. The first is that a corruption taken strictly is a sudden or instantaneous change so that it occurs simultaneously with its terminus, that is, its end stage. In medieval terminology, the change and the having-beenchanged - the mutatio and the mutatum esse - occur simultaneously. The terminus of a corruption is the non-being of the thing subject to corruption. The second condition is that the thing to be corrupted persists until the instant in which its corruption takes place. Let me call these two conditions the simultaneity-condition (i.e., simultaneity of a corruption and of its terminus) and the persistence-condition respectively.

How these two conditions are supposed to work is well illustrated with the example of a substantial change from water to air, a change in which water is corrupted. The idea here is that water is first subject to a process of alteration - a qualitative change - a process in which some of its qualities undergo a change (e.g., water becomes hotter and hotter), and at the end of this process water is transformed into air, that is, the corruption of water occurs. The alteration of water is a temporal change, that is, it takes some time. Suppose it lasts for the period of time between instant $t 1$ and instant $t 2$. Now water persists in the

${ }^{18}$ Gualterus Burlaeus, In Physicam IV (ed. cit., f. 124vb): “[...] quod probo sic. Res quae proprie est corruptibilis semper habet esse quousque corrumpatur. Similiter corruptio quae est mutatio, cum sit subita, simul est cum termino mutationis. Et ex his arguo sic. Si instans proprie corrumperetur, instans semper maneret quousque sua corruptio esset. Si igitur instans corrumpitur, aut corrumpitur in instanti in quo est aut in alio. $\mathrm{Si}$ in instanti in quo est seu quando est, tunc instans simul esset cum sua corruptione; sed corruptio quae est mutatio simul est cum termino corruptionis et terminus corruptionis est non esse rei quae corrumpitur; igitur si instans corrumpitur quando est, instans simul esset cum suo non esse, et sic instans simul esset et non esset, quod est impossibile. Nec est etiam dare quod instans corrumpatur in alio instanti, quia tunc instans maneret et continue usque ad aliud instans in quo corrumpitur, et sic instans maneret per totum tempus medium inter ipsum instans et instans suae corruptionis, quod est impossibile. Et ideo dico quod instans proprie non corrumpitur. Haec igitur ratio fundatur super duo fundamenta, quorum primum est quod corruptio subita simul est cum termino corruptionis. Secundum quod res corruptibilis continue manet usque ad instans suae corruptionis. Et ista nota sunt per se." 
whole period of time from $t 1$ until $t 2$, but not including $t 2$. For $t_{2}$ is the instant in which the corruption of water occurs and so its terminus obtains too, so that at $t 2$ water no longer exists; air instead exists at $t 2$.

This description of a corruption strictly is in line with Aristotle's account of the instant of change in Physics VIII, 8: the instant of change is the first instant in which the new state obtains and not the last instant in which the former state does. ${ }^{19}$

Going back to our case, Burley uses the two conditions of a corruption taken strictly as premises in support of Aristotle's argument against the corruption of an instant. More specifically, the question is 'when is an instant subject to corruption?' and the two possible replies are (a) in the instant in which it is and (b) in a later instant, when it is not. The simultaneity-condition rules out the first reply: the instant of corruption is an instant in which the thing subject to corruption is not. The persistence-condition rules out the second reply: if the corruption of an instant $t$ occurred in a later instant $s$, instant $t$ should persist until instant $s$, which is against the hypothesis that an instant lasts only for one instant. This shows that Aristotle's argument against the corruption of the instant is indeed valid if corruption is taken strictly.

Burley maintains, however, that an instant can be subject to corruption taken broadly:

However, if we speak of corruption taken in a broad way, that is, insofar as it extends to every taking-on of non-being after being, then I say that an instant is subject to corruption and ceases to be because it has non-being after being; but this kind of corruption is not a change, but is a ceasing to be. And that an instant is corrupted in this way is clear because otherwise the same instant would remain in the whole time and so all the things that were would have been in the same instant, which is impossible, as has been argued above; therefore etc. ${ }^{20}$

\footnotetext{
${ }^{19}$ See above, oo.

${ }^{20}$ Gualterus Burlaeus, In Physicam Aristotelis Expositio et Quaestiones IV (ed. cit., f. 124vb): "Sed loquendo de corruptione large accepta, secundum scilicet quod se extendit ad omnem acceptionem non esse post esse, sic dico quod instans corrumpitur et desinit esse quia habet non esse post esse (esse post
} 
Thus, an instant ceases to be and so passes from being to nonbeing, although this does not happen through a change.

\section{$4 \quad$ The Logic of Beginning and Ceasing}

It is not yet clear, however, why Aristotle's argument does not apply to the corruption of an instant taken broadly as ceasing to be. Certainly we can reformulate Aristotle's question for the ceasing to be of an instant and ask 'when does instant $t$ cease to be?' Burley maintains that we can give a satisfactory answer to this question, namely, that instant $t$ ceases to be at $t$ itself, that is, when that instant is. Doesn't it follow from this reply that instant $t$ both is and is not at $t$, as Aristotle's argument concludes? Burley denies this by appealing to the 'logic' of the beginning and ceasing, that is, to the logical analysis of sentences about beginning and ceasing:

And if it is objected that the main argument giving rise to this question still holds, because if an instant is subject to corruption in whatsoever way or ceases to be, this happens either when it is or when it is not, and so the difficulty comes back, I say that by being subject to corruption broadly speaking and by ceasing to be I mean the same, likewise by being subject to generation broadly speaking and by beginning to be. But 'to cease' has two expositions, and thus two senses, because in one way the exposition of 'to cease' is through the position of the present and the negation of the future, that is: 'this ceases to be' is equivalent to 'this is and this never afterwards will be'. In another way the exposition of 'to cease' is through the negation of the present and the position of the past, and in this way the exposition of 'this ceases to be' is 'this is not and this immediately beforehand was'. Likewise I say that 'to begin' has two expositions, that is, in one way through the position of the present and the negation of the past. And in this way the exposition of the sentence 'this begins to be' is 'this is and this never

non esse ed.); sed haec corruptio non est mutatio, sed est desinitio esse. Et quod instans hoc modo corrumpatur patet, quia aliter maneret idem instans in toto tempore et sic omnia quae fuerunt fuerunt in eodem instanti, quod est impossibile, ut argutum est supra; igitur etc. " 
beforehand was'. In another way the exposition of 'to begin' is through the negation of the present and the position of the future, and in this way the exposition of 'this begins to be' is 'this is not and this immediately afterwards will be'. And the same kinds of expositions are given for 'to be subject to generation' and 'to be subject to corruption' taken broadly. ${ }^{21}$

Burley's explanation is in short the following. The sentence 'this thing ceases to be' has two expositions, that is, it can be understood/expanded in two ways. In one way as asserting the position of the present and the negation of the future, that is, as 'this thing now is and immediately afterwards will not be'; in another way as asserting the negation of the present and the position of the past, that is, as 'this thing now is not and immediately beforehand was'. A dual exposition of a similar kind holds for a sentence about the beginning of something: 'this thing begins to be' can be understood either as 'this thing now is and immediately beforehand was not' (position of the present and negation of the past) or as 'this thing now is not and immediately afterwards will be' (negation of the present and position of the future).

Applying this logical analysis of beginning and ceasing to the case of an instant, Burley maintains that the sentence instant $t$ ceases to be' is true if ceasing is understood as position of the present and negation of the future, as 'instant $t$ now is and

${ }^{21}$ Gualterus Burlaeus, In Physicam IV (ed. cit., ff. 124vb-125ra): "Et si dicitur quod ratio principalis dubitationis manet, quia, si instans corrumpatur qualitercumque vel desinat esse, aut igitur quando est vel quando non est et redit difficultas, dico quod idem intelligo per corruptionem large loquendo et per desinere esse et per generari et per incipere esse. Sed 'desinere' exponitur dupliciter, et sic habet duplicem intellectum, quia uno modo 'desinere' exponitur per positionem praesentis et negationem futuri, et sic 'hoc desinit esse' <exponitur sic>: 'hoc est et hoc numquam postea erit'. Alio modo 'desinere' exponitur per negationem praesentis et per positionem praeteriti, et sic 'hoc desinit esse' exponitur sic: 'hoc non est et hoc sine medio fuit'. Dico similiter quod 'incipere' exponitur dupliciter, videlicet uno modo per positionem praesentis et negationem praeteriti, et sic 'hoc incipit esse' exponitur sic: 'hoc est et hoc numquam prius fuit'. Alio modo exponitur per negationem praesentis et positionem futuri, et sic 'hoc incipit esse' sic exponitur: 'hoc non est et hoc statim sine medio erit'. Et eodem modo debet exponi generari et corrumpi largo modo accepta." (I have emended the text of the edition.) 
immediately afterwards will not be', so that instant $t$ ceases to be when it is. It is not true, however, if ceasing to be is understood as negation of the present and position of the past. The sentence 'instant $t$ now is not and immediately beforehand was' can only be true if there is an instant $s$ immediately before instant $t$, which is against the assumption of the continuity of time:

Therefore, when it is asked whether an instant is subject to corruption or ceases to be when it is or when it is not, I reply that if we give the exposition of 'to be subject to corruption' or 'to cease to be' through the position of the present and the negation of the future, then an instant is subject to corruption when it is, because when an instant is, it is true to say that this instant is and that it never afterwards will be. But when the exposition of 'to be subject to corruption' or 'to cease to be' is given through the negation of the present and the position of the past, then I say that it is never true to say of an instant that it is subject to corruption, because it is never true to say of an instant that it now is not and immediately beforehand was, except if instants were immediate one to another. ${ }^{22}$

Burley offers a similar analysis of the beginning of the being of an instant. The sentence 'instant $t$ begins to be' is true if beginning is understood as position of the present and negation of the past, that is, as 'this instant now is and beforehand was not'; it is not true if beginning is understood as negation of the present and position of the future, that is, as 'this instant now is not but immediately afterwards will be', again because of the continuity of time. Accordingly, an instant $t$ both begins to be and ceases to be at instant $t$. More generally, any instantaneous thing lasting for only one instant $t$ is such that it both begins to

${ }^{22}$ Gualterus Burlaeus, In Physicam IV (ed. cit., f. 125ra): "Cum igitur quaeritur aut instans corrumpitur vel desinit esse quando est vel quando non est, dico quod exponendo 'corrumpi' vel 'desinere esse' per positionem praesentis et negationem futuri, sic instans corrumpitur quando est, quia quando aliquod instans est, verum est dicere quod hoc instans est et numquam postea erit. Sed cum 'corrumpi' vel 'desinere esse' exponitur per negationem praesentis et positionem praeteriti (futuri ed.), sic dico quod numquam est verum dicere de aliquo instanti quod ipsum corrumpitur, quia numquam est verum dicere de aliquo instanti quod (ipsum corrumpitur quia add. ed.) nunc non est et immediate ante hoc fuit nisi instans esset immediatum instanti." 
be and ceases to be at $t$. Thus, as Burley points out, beginning and ceasing for instantaneous things are not incompatible states. Indeed, the two sentences that express the correct formulations of their beginning and ceasing respectively can both be true simultaneously. For they concur in the condition of the position of the present, and their distinctive conditions - negation of the past and negation of the future respectively - are compatible. ${ }^{23}$

The rationale behind this logical analysis of the beginning and ceasing of instantaneous things is that, given the assumption of the continuity of time, it is only the non-being of such things and not also their being that can fall on the side of (an extended period of) time rather than on the side of an instant of time. To see this point, compare the sentences 'water ceases to be at instant $t$ ' and 'instant $t$ ceases to be at $t$ '. The sentence about water can be true in both expositions of 'ceasing': (i) 'water is at $t$ and immediately after $t$ will not be' and (ii) 'water is not at $t$ and immediately before $t$ was'. Now, because of the continuity of time, what comes immediately before an instant $t$ is an extended period of time ending at $t$ (not including $t$ ) and not another instant, given that there is not an instant next to instant $t$. Likewise, what comes immediately after instant $t$ is an extended period of time beginning at $t$. Therefore, for sentence (i) to be true, the non-being of water must last for an extended period of time, whereas for sentence (ii) to be true, the being of water must last for an extended period of time. Water is the kind of thing that can satisfy both conditions: both its non-being and its being can last for some time. In the case of an instant, however,

${ }^{23}$ Gualterus Burlaeus, In Physicam IV (ed. cit., f. 125ra): "Sed contra illud videtur esse quia, quando instans est, tunc incipit esse et generatur largo modo loquendo; ergo quando est, non corrumpitur nec desinit esse, quia generatio et corruptio et similiter inceptio et desinitio sunt opposita. Dicendum est quod exponendo utrumque, scilicet 'incipere' et 'desinere', per positionem praesentis, sic non sunt opposita, quoniam ista non sunt opposita ' $a$ est et $a$ numquam erit' et ' $a$ est et $a$ numquam prius fuit'. Sed exponendo unum illorum per positionem praesentis et aliud per negationem praesentis, sic sunt opposita. Et tunc dico quod hoc instans praesens incipit esse exponendo 'incipere esse' per positionem praesentis et negationem praeteriti, quia hoc instans est et hoc instans numquam prius fuit. Et etiam haec est vera 'hoc instans desinit esse' exponendo 'desinere' per positionem praesentis et negationem futuri, quoniam hoc instans est et numquam postea erit. Et tunc dico quod inceptio et desinitio, generatio et corruptio, hoc modo <non> sunt opposita." 
and more generally of things whose existence lasts for only one instant, there is not such a choice: it is only their non-being that can last for some time. Therefore, for instantaneous things the only true sentences about their ceasing to be are those of kind (i), in which it is their non-being that is required to last for some time.

\section{$5 \quad$ The Having Ceased to Be of an Instant}

As pointed out above, there are two questions that arise from Burley's discussion when this is compared to the original Aristotelian puzzle. ${ }^{24}$ Given that for Burley's solution to the problem of the ceasing to be of an instant to be plausible, he needs to distinguish between its ceasing to be (in the present tense) and its having ceased to be (in the perfect tense), the first question is whether and how he actually draws this distinction. The second question is what his solution to problem of the having ceased to be of an instant is, that is, his reply to the question 'When has an instant $t$ first ceased to be?' In the following passage Burley provides a reply to both questions:

And when it is said that, if an instant is subject to corruption when it is, then the corruption of an instant would occur when that instant is, and when a corruption occurs, then its terminus occurs, therefore, if an instant is when it is subject to corruption, it follows that an instant simultaneously is and is not, I say that an instant is subject to corruption when it is, if we give the exposition of 'to be subject to corruption' through the position of the present and the negation of the future, and in this case a corruption is not a change, but the taking-on of non-being after being without intermediates. And I say that this kind of corruption that is not a change does not occur simultaneously with the terminus of the change; nor is an instant subject to corruption in the proper way, as has been said, because a corruption taken properly is always the end of a preceding alteration and this kind of corruption occurs simultaneously with the terminus of the corruption. But corruption taken in the broad way, with the

${ }^{24}$ See above, oo. 
exposition that has been explained, that is, through the position of the present, precedes the having-been-corrupted. And I say that in such things it is not possible to give a first having-been-corrupted. ${ }^{25}$

Burley here addresses an argument against his solution to the problem of the corruption of the instant. The argument concludes that his solution runs into the original problem of the Aristotelian puzzle, that is, it leads to posit that an instant $t$ both is and is not at the same time. The relevant premises of the argument are:

(i) when instant $t$ is subject to corruption (ceases to be), it is;

(ii) a corruption and its terminus occur simultaneously, that is, the ceasing to be and the having-ceased to be occur simultaneously;

(iii) when instant $t$ is in the terminus of its corruption, that is, has ceased to be, it is not;

(iv) therefore, instant $t$ both is and is not when it is subject to corruption.

Now, conclusion (iv) clearly follows from premises (i)-(iii). Premise (i) is Burley's solution to the problem of the ceasing to be of an instant. Premise (iii) is evidently true. So the only way for Burley to defend his solution against the charge of implying a contradiction is rejecting premise (ii), that is, the claim that a corruption and its terminus occur simultaneously. Indeed, Burley rejects this premise, appealing to his distinction between corruption taken strictly and corruption taken broadly. The

${ }^{25}$ Gualterus Burlaeus, In Physicam IV (ed. cit., f. 125ra): "Et quando dicitur quod, si instans corrumpitur quando est, tunc corruptio instantis esset quando instans est, et quando corruptio est suus terminus est, ergo si instans est quando corrumpitur, sequitur quod instans simul est et non est, dico quod instans corrumpitur quando est, exponendo 'corrumpi' per positionem praesentis et negationem futuri; et tunc corruptio non est mutatio sed est acceptio non esse <post esse $>$ sine medio. Et dico quod huiusmodi corruptio quae non est mutatio non est simul cum termino mutationis; nec corrumpitur proprie instans, ut dictum est, quia corruptio proprie dicta semper est finis alterationis praecedentis et talis corruptio simul est cum termino corruptionis. Sed corruptio large accepta, exponendo 'corruptionem' ut dictum est, scilicet per positionem praesentis, praecedit corruptum esse. Et dico quod in talibus non est dare primum corruptum esse." 
relevant difference between the two is about what I have called the simultaneity-condition. A corruption taken strictly is simultaneous with its terminus, but a corruption taken broadly is not simultaneous with its terminus, but occurs before its terminus. So premise (ii) is only valid for corruption taken strictly. But the corruption ascribed to an instant in premise (i) is a corruption taken broadly, for which premise (ii) does not hold. Thus, it is with the uplift of the simultaneity-condition from corruption taken broadly that Burley replies to the first question about the difference between the ceasing to be and the having ceased to be of an instant. Its ceasing to be, at which its being obtains, is not simultaneous but temporally prior to its having ceased to be, at which its non-being obtains.

As to the second question, 'when has instant $t$ first ceased to be?', Burley's reply at the very end of the passage above is that there is not a first instant at which instant $t$ has ceased to be. To see his point, let us consider again the exposition of the ceasing to be of instant $t$ in terms of the position of the present and the negation of the future: instant $t$ now is and immediately afterwards will not be'. Thus, the non-being of instant $t$ obtains immediately after instant $t$; but what comes immediately after instant $t$ is an extended period of time, which, because of its continuity, contains no first instant or first part. In conclusion, if Aristotle's original question is the past-tense one that asks 'when has instant $t$ first ceased to be?', then according to Burley's analysis there is no answer to this question. Or better, the only answer we can give is that instant $t$ has ceased to be in the period of time starting at $t$, and there is no more precise answer to be given: we cannot point to an instant within this period at which instant $t$ has first ceased to be. ${ }^{26}$ Yet Burley argues that the instant does cease to be and that we can make perfect sense of its ceasing to be by maintaining that it ceases to be when it is.

26 On similar solutions to the Aristotelian puzzle, see Coope, Time for Aristotle, 28-29. 